\title{
Romnalda ophiopogonoides (Asparagales: Laxmanniaceae), a new and endangered species from the Wet Tropics bioregion of north-east Queensland
}

\author{
John G. Conran' ${ }^{1}$ Paul I. Forster ${ }^{2}$ and Matthew Donnon ${ }^{1}$ \\ ${ }^{1}$ Australian Centre for Evolutionary Biology and Biodiversity, Discipline of Ecology \& Evolutionary \\ Biology, DP312, School of Earth and Environmental Sciences, The University of Adelaide, SA \\ 5005, Australia \\ ${ }^{2}$ Queensland Herbarium, Brisbane Botanic Gardens, Mt Coot-tha Road, Toowong, Qld 4066, \\ Australia \\ Author for correspondence: john.conran@adelaide.edu.au
}

\begin{abstract}
Romnalda ophiopogonoides Conran, P.I.Forst. et Donnon sp. nov. from the Cape Tribulation -Daintree area in the Wet Tropics bioregion of north-east Queensland is described, illustrated and compared with related species. A conservation status of Endangered is proposed. Notes on habitat, distribution and cytology and a key to the species of Romnalda are provided.
\end{abstract}

\section{Introduction}

The genus Romnalda P.F.Stevens (Asparagales: Laxmanniaceae) was erected to accommodate three species of erect-stemmed, strap-leaved, generally stilt-rooted rainforest monocots from northern Australia and New Guinea. Although superficially similar to Lomandra R.Br., especially the tropical L. banksii (R.Br.) Ewart, it differs in several features, not least of which is that Romnalda is always hermaphrodite, whereas all species of Lomandra are dioecious (Stevens 1978), or only rarely and sporadically bear a few hermaphrodite flowers on otherwise unisexual inflorescences (Briggs 1986). In this, Romnalda is much more like other Lomandroideae sensu Conran (1998) and in particular, superficially resembles the rare, strap-leaved, cauline understorey herb Chamaexeros longicaulis T.D.Macfarlane from moist tall open forests in far south-west Western Australia.

Romnalda papuana (Lauterb.) P.F.Stevens is known from five localities in lowland rainforest in Papua New Guinea (including New Britain) and the island of Pulau Yapen

Paper from the Australian Systematic Botany Society Conference held in Darwin, September 2007 
in Indonesian Papua (Stevens 1978). The species is rare, mostly unprotected and in need of conservation (Shapcott et al. 2006). Henderson (1986) recognised two species in Australia: R. grallata R.J.F.Hend. from several populations in two high altitude $(>600 \mathrm{~m})$ cloud forest regions in the Daintree area of the Wet Tropics bioregion of north-east Queensland, where it is currently listed as Rare under the Commonwealth Environment Protection and Biodiversity Conservation Act 1999 (EPBC 1999) (DEH 2006), although it has been de-listed in Queensland. A second species, R. strobilacea R.J.F.Hend. \& P.R.Sharpe, is known from a small number of rainforest pockets on basaltic soils in south-east Queensland (Logan River Branch SGAP (Queensland Region) Inc. 2005) and is listed as Vulnerable under both Federal (EPBC 1999) and State (Nature Conservation Act 1992) legislation.

Since Henderson's (1986) treatment, another taxon with restricted distribution has been discovered in the Cape Tribulation - Daintree area (specifically in the region of Cooper Creek) in the Wet Tropics bioregion. This taxon has been known under the HISPID code names of Romnalda sp. (Roaring Meg P.I.Forster+ PIF4402) (Forster 1994) or R. sp. (Cooper Creek P.I.Forster+ PIF4402) (Forster 1997, 2002, Wang 2007). Although bearing some similarities to $R$. grallata, the taxon differs in a range of features and largely occupies a different niche of the Wet Tropics bioregion, although there are some places where the two are sympatric.

Population genetic studies of Romnalda (Shapcott et al. 2006) showed clearly that the Cooper Creek plants were distinct from $R$. grallata, although occasional hybridisation occurs when the two species are sympatric. The new taxon, described below as Romnalda ophiopogonoides, is regarded as Endangered (Shapcott et al. 2006), although it has yet to be officially listed as such. It is given this status because there are only about 500 plants at the three known localities. many of which are in areas of private land adjacent to National Parks, or along walking tracks where they may be subject to tramping effects.

\section{Methods}

Herbarium specimens of $R$. ophiopogonoides and other Romnalda species lodged at BRI and $\mathrm{AD}$ were examined for as many populations as possible using Scanning Electron Microscopy (SEM) and a stereo dissecting microscope, as were living specimens of these species growing at ADU. Morphological descriptions were based on fresh, dried and spirit material. All three species of Australian Romnalda have been examined in the field and vouchered by the second author.

Leaf anatomy studies used dried material for consistency, with the samples rehydrated in warm water. Transverse sections were cut with a sliding microtome at 10-15 $\mu \mathrm{m}$, stained with $1 \%$ aqueous Toluidine Blue and mounted in CrystalMount ${ }^{\circledR}$. Cuticles were prepared following the methods of Christophel and Lys (1986), stained in 0.5\% aqueous Crystal Violet, mounted in CrystalMount ${ }^{\circledR}$ and examined using Nomarski Differential Interference Contrast microscopy. The cuticles were compared using a modified version of the cuticular character set for Cordyline Comm. ex R.Br. (Conran 1997).

Chromosome counts were made from actively growing root tips excised from cultivated plants and pre-treated for 2 hours in $250 \mathrm{ppm} 8$-hydroxyquinoline, as well as meiotic counts from buds where available. Fixation used Bradley's fixative (4:3:1 chloroform: ethanol: glacial acetic acid) for at least 24 hours followed by storage in $70 \%$ ethanol at $-20^{\circ} \mathrm{C}$. Root tips were hydrolysed for 20 minutes in $5 \mathrm{~N} \mathrm{HCl}$ at $20^{\circ} \mathrm{C}$, and rinsed 
in distilled water $(2 \times 10 \mathrm{mins})$. Anthers and root tips were stained for $20 \mathrm{~min}$ and squashed in a drop of Carbol Fuchsin (Prakash 2000). Coverslips were removed by the freeze method of Conger \& Fairchild (1953) using a $-80^{\circ} \mathrm{C}$ freezer, the slides air-dried and specimens mounted in Gurr's Euparal ${ }^{\circledR}$. Chromosome spreads were counted and photographed under oil-immersion.

\section{Results and Discussion}

\section{Morphology}

Comparison of $R$. ophiopogonoides with the other members of the genus shows that it differs in a range of morphological features (Table 1). The stems are shorter than the other Australian taxa and the leaves are smaller and generally with fewer teeth, and unlike $R$. grallata, are concolorous. In addition $R$. grallata lacks the persistent bracts of $R$. ophiopogonoides. The new species is very unlike $R$. strobilacea in inflorescence size and flower cluster position. The flowers are similar in size to R. papuana, but the stamens of $R$. ophiopogonoides differ in their combination of filament and anther size and shape characteristics from the rest of the genus. Similarly, the ovary and style are smaller than in $R$. papuana. The fruit seems to be intermediate in size between R. grallata and the other species although this is based on data from the single known, not quite mature, capsule.

\section{Anatomy}

Investigation of the epidermal anatomy of the three Australian species of Romnalda (Fig. 1) showed that they differed both in mean cell size as well as aspects of cuticular sculpturing (Table 2). In general, the cells in R. ophiopogonoides were larger on both surfaces than in the other two taxa, but the stomata were intermediate in size and the subsidiary cells closer in size to $R$. grallata. The cuticles of $R$. ophiopogonoides were unsculptured, again resembling R. grallata.

Internalleaf anatomy for the Australian species (Fig. 2) showed that therewere differences in thickness and fibre distribution (Table 2). The leaves of $R$. ophiopogonoides were thinner than the other two, and although resembling $R$. grallata in lacking hypodermal fibres and possessing fibre bundle extensions and leaf marginal fibre masses, the new species differed from both $R$. grallata and $R$. strobilacea in the rarity of fibres scattered in the chlorenchymatous outer mesophyll.

\section{Cytology}

The chromosome number for the new species is $2 n=16$ (Fig. 3), the same as that reported for R. grallata by Henderson (1986).

\section{Biogeography and Ecology}

The genus was regarded by van Steenis (1985) as an Australian element that had expanded to Malesia. Within New Guinea, the isolated Vogelkop and island disjunctions follow a recurring pattern seen in other organisms with low dispersal ability and/or specific habitat needs such as birds of paradise, invertebrates and numerous plants (Heads 2001). This pattern is thought to have arisen as the Australian plate moved northwards, accreting land masses to the north as it went. 
Table 1. Morphological comparison of Romnalda spp.

\begin{tabular}{|c|c|c|c|c|}
\hline Character & R. grallata & R. ophiopogonoides & R. papuana* & R. strobilacea \\
\hline $\begin{array}{l}\text { Max. stem length } \\
(\mathrm{cm})\end{array}$ & 40 & 6 & 5 & 10 \\
\hline $\begin{array}{l}\text { Leaf length } \times \\
\text { width }(\mathrm{mm})\end{array}$ & $120-350 \times 7-16$ & $60-120 \times 3-5$ & $220-380 \times 4-5$ & $500-800 \times 8-13$ \\
\hline Leaf apical teeth & $4-8$ & $3-4$ (rarely 5) & $5-12$ & $\begin{array}{l}\text { absent (rarely } \\
1-3)\end{array}$ \\
\hline Leaf surfaces & discolorous & concolorous & concolorous & $\begin{array}{l}\text { inconspicuously } \\
\text { discolorous }\end{array}$ \\
\hline $\begin{array}{l}\text { Inflorescence } \\
\text { length }(\mathrm{cm})\end{array}$ & $9-30$ & $8-20$ & $\leq 20$ & $60-90$ \\
\hline Flower clusters & $\begin{array}{l}\text { axillary and along } \\
\text { branches }\end{array}$ & $\begin{array}{l}\text { axillary and along } \\
\text { branches }\end{array}$ & $\begin{array}{l}\text { axillary, } \\
\text { branches and } \\
\text { branch apices }\end{array}$ & branch apices \\
\hline Bract persistence & withering early & persistent & persistent & persistent \\
\hline Sepal shape & ovate-deltoid & deltoid & ovate & elliptic \\
\hline $\begin{array}{l}\text { Sepal length } \times \\
\text { width }(\mathrm{mm})\end{array}$ & $\begin{array}{l}3.5-4.0 \times \\
1.1-1.4\end{array}$ & $\begin{array}{l}3.0-3.5 \times \\
1.0-1.2\end{array}$ & $\begin{array}{l}3.0-3.5 \times \\
1.0-1.2\end{array}$ & $\begin{array}{l}2.8-3.2 \times \\
0.8-1.1\end{array}$ \\
\hline Petal shape & elliptic-oblong & ovate-elliptic & elliptic & $\begin{array}{l}\text { obovate- } \\
\text { obcordate }\end{array}$ \\
\hline $\begin{array}{l}\text { Petal length } \mathrm{x} \\
\text { width }(\mathrm{mm})\end{array}$ & $\begin{array}{l}4.0-4.5 \times \\
1.2-1.5\end{array}$ & $\begin{array}{l}3.5-4.0 \times \\
1.1-1.4\end{array}$ & $\begin{array}{l}3.5-3.8 \times \\
0.7-0.8\end{array}$ & $\begin{array}{l}2.3-2.7 \times \\
0.6-0.8\end{array}$ \\
\hline Filament shape & linear & $\begin{array}{l}\text { narrow triangular } \\
\text { towards base }\end{array}$ & $\begin{array}{l}\text { narrow } \\
\text { triangular } \\
\text { towards base }\end{array}$ & $\begin{array}{l}\text { triangular } \\
\text { towards base }\end{array}$ \\
\hline $\begin{array}{l}\text { Filament length } \\
\text { outer; inner; } \\
\text { anther (mm) }\end{array}$ & c. $2.0 ; 2.5 ; 1.0$ & c. $2.0 ; 2.0 ; 0.6$ & c. $2.2 ; 2.5 ; 1.0$ & c. $1.0 ; 0.6 ; 0.6$ \\
\hline $\begin{array}{l}\text { Ovary length } \\
(\mathrm{mm})\end{array}$ & c. 1.5 & c. 0.75 & c. 1.5 & c. 1.0 \\
\hline Style shape & $\begin{array}{l}\text { apically } \\
\text { geniculate }\end{array}$ & $\begin{array}{l}\text { straight to curved } \\
\text { apically }\end{array}$ & straight & curved \\
\hline Style length (mm) & $3.25-3.75$ & $1.75-2.25$ & $0.8-1.2$ & $0.75-1.0$ \\
\hline Fruit shape & $\begin{array}{l}\text { ovoid, short- } \\
\text { beaked }\end{array}$ & $\begin{array}{l}\text { hemispherical, long- } \\
\text { beaked }\end{array}$ & $\begin{array}{l}\text { ovoid, short- } \\
\text { beaked }\end{array}$ & $\begin{array}{l}\text { depressed } \\
\text { globular, } \\
\text { apiculate }\end{array}$ \\
\hline $\begin{array}{l}\text { Fruit length } \times \\
\text { width }(\mathrm{mm})\end{array}$ & C. $10 \times 10$ & C. $8 \times 5.5$ & $4-5 \times 3-4$ & $4.5-6 \times 4.5-6$ \\
\hline $\begin{array}{l}\text { Chromosome } \\
\text { number }\end{array}$ & $n=8 ; 2 n=16$ & $n=8 ; 2 n=16$ & not known & $2 n=16$ \\
\hline
\end{tabular}

* data mostly from Stevens (1978). 

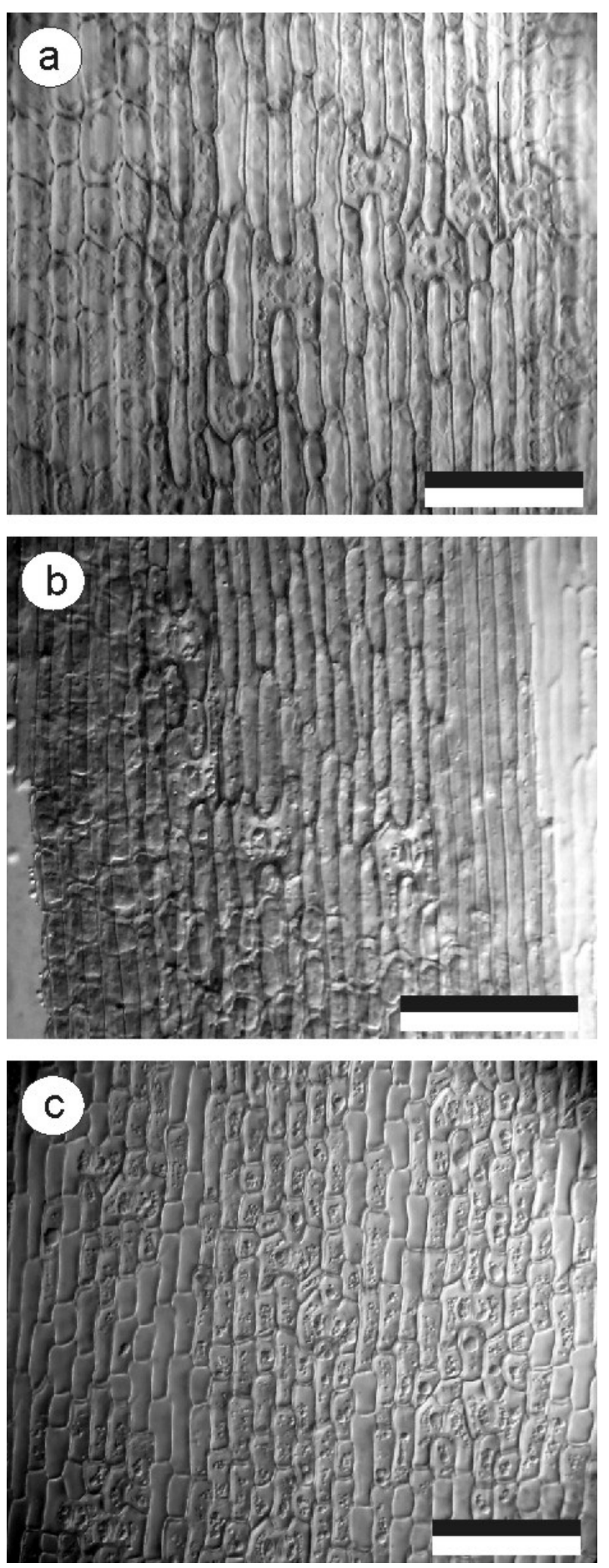

Fig. 1. Romnalda leaf abaxial epidermal anatomy. a, R. grallata, from Conran 2299 (ADU); b, R. ophiopogonoides, from Sankowsky 2717 (BRI, ADU); c, R. strobilacea, from Conran 2300 (ADU). Scale bars $=50 \mu \mathrm{m}$. 

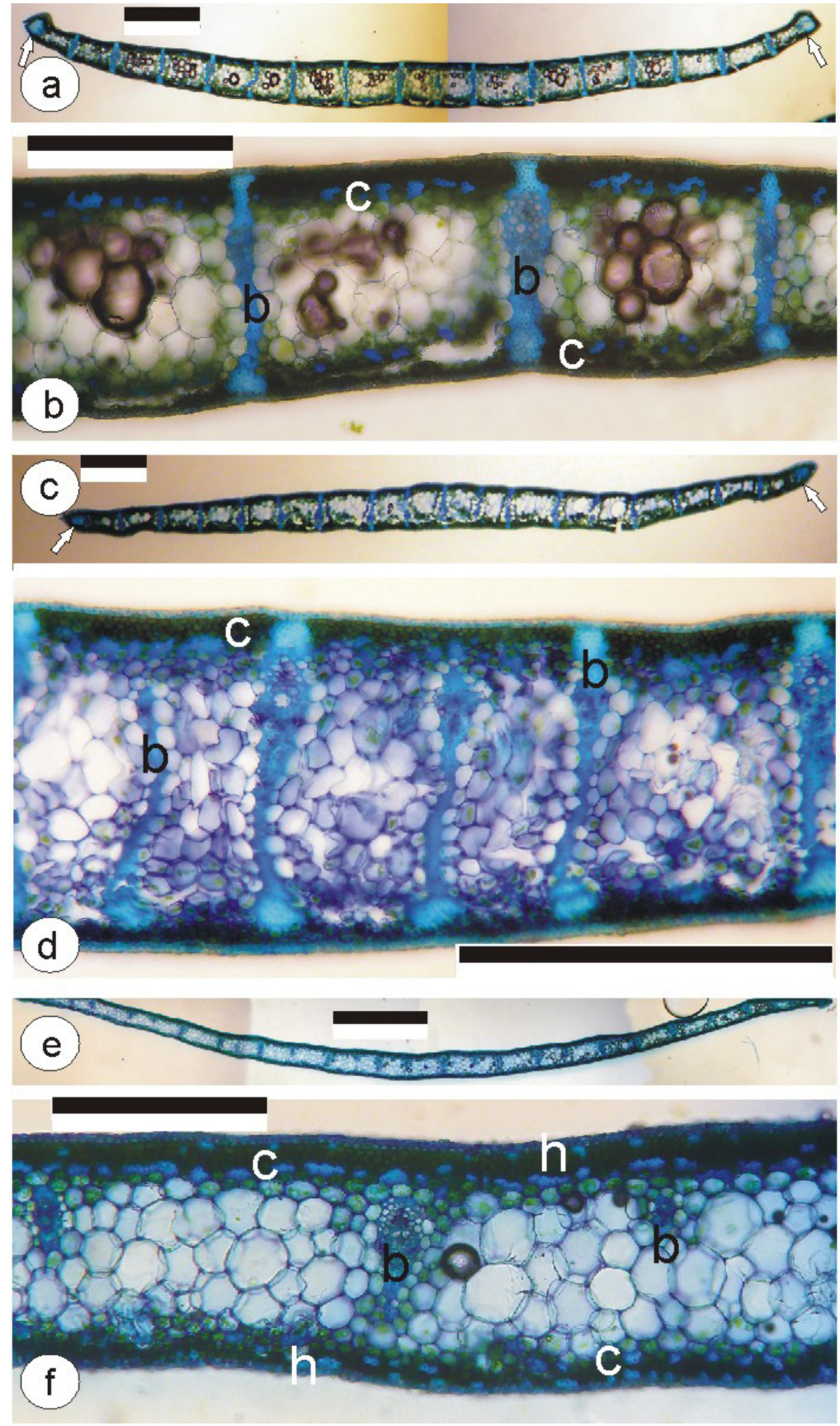

Fig. 2. Romnalda leaf internal anatomy. a, c, e, lamina in transverse section; $\mathbf{b}, \mathbf{d}, \mathbf{f}$, detail of vascular bundles and associated tissues. a-b, R. grallata, from Conran 2299 (ADU); c-d, R. ophiopogonoides, from Sankowsky 2717 (BRI, ADU); e-f, R. strobilacea, from Conran 2300 $(\mathrm{ADU}) . \mathbf{b}=$ fibres associated with vascular bundles, $\mathbf{c}=$ fibres associated with chlorenchyma, $\mathbf{h}=$ hypodermal fibres, arrows indicate marginal fibre bundles. Scale bars $\mathbf{a}, \mathbf{c}, \mathbf{e},=1 \mathrm{~mm}$; b, d, f, $=250 \mu \mathrm{m}$. 


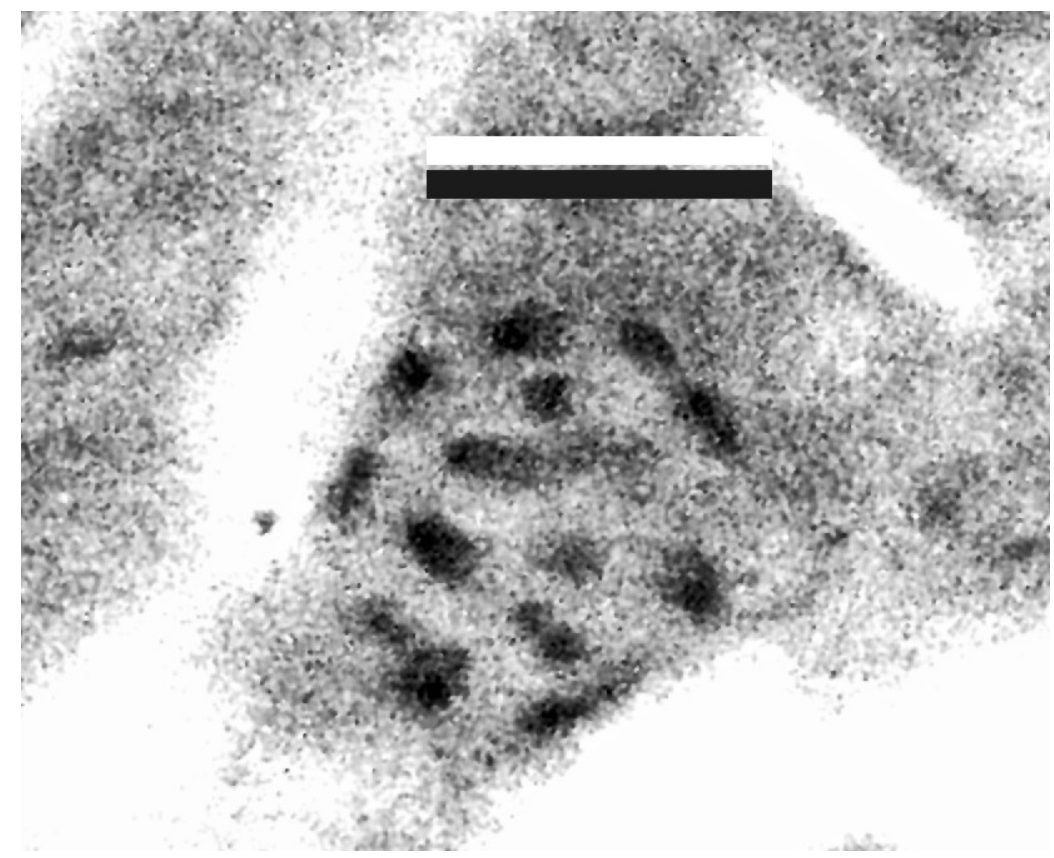

Fig. 3. Romnalda ophiopogonoides chromosomes, voucher from Sankowsky 2717 (BRI, ADU). Scale bar $=5 \mu \mathrm{m}$.

The similarly narrow and disjunct population patterns in Australia suggest that Romnalda is restricted through its apparently low dispersal ability and relatively specific habitat requirements. Plants of the Australian species show no specific adaptations for dispersal and the seeds are unprotected and short lived (JGC unpubl. obs.). There is some evidence that the plants can disperse locally along waterways by fragmentation of the colonies during the wet season (G. Sankowsky, pers. comm.), but this is a 'downhill only' option and not likely to lead to long distance dispersal.

\section{Taxonomy}

Romnalda ophiopogonoides Conran, P.I.Forst. et Donnon, sp. nov.

Fig. 4

Affinis $R$. grallatae. Herba caespitosa; radices gralliformes. Folia numerosa, $6-12 \mathrm{~cm}$ longa, minute 3(-4) -dentata. Flores fasciculati in ramulis et axillis portati; bracteae numerosae, persistentes. Petala longiora sepalis; stylus ovario minimum duplo longior.

Holotype. Queensland: Cook District: Mount Sorrow track before razorback, Daintree National Park, $2.5 \mathrm{~km}$ W of Cape Tribulation, P.I. Forster PIF21988, R. Booth, R. Jago \& R. Jensen, 2 Dec 1997 (BRI [1 sheet + spirit]). (Iso: MEL, QRS).

Plants 10-15 cm tall, tufted to clump forming. Stems to c. $6 \mathrm{~cm}$ long, branching, erect with wiry, stilt-like adventitious supporting roots. Leaves numerous, 6-12 cm long, 3-5 mm wide, concolorous, obtuse to truncate with 3-4 (rarely 5) minute apical teeth. Inflorescence $8-20 \mathrm{~cm}$ long, simple or few-branched; peduncle dark purplish green; 

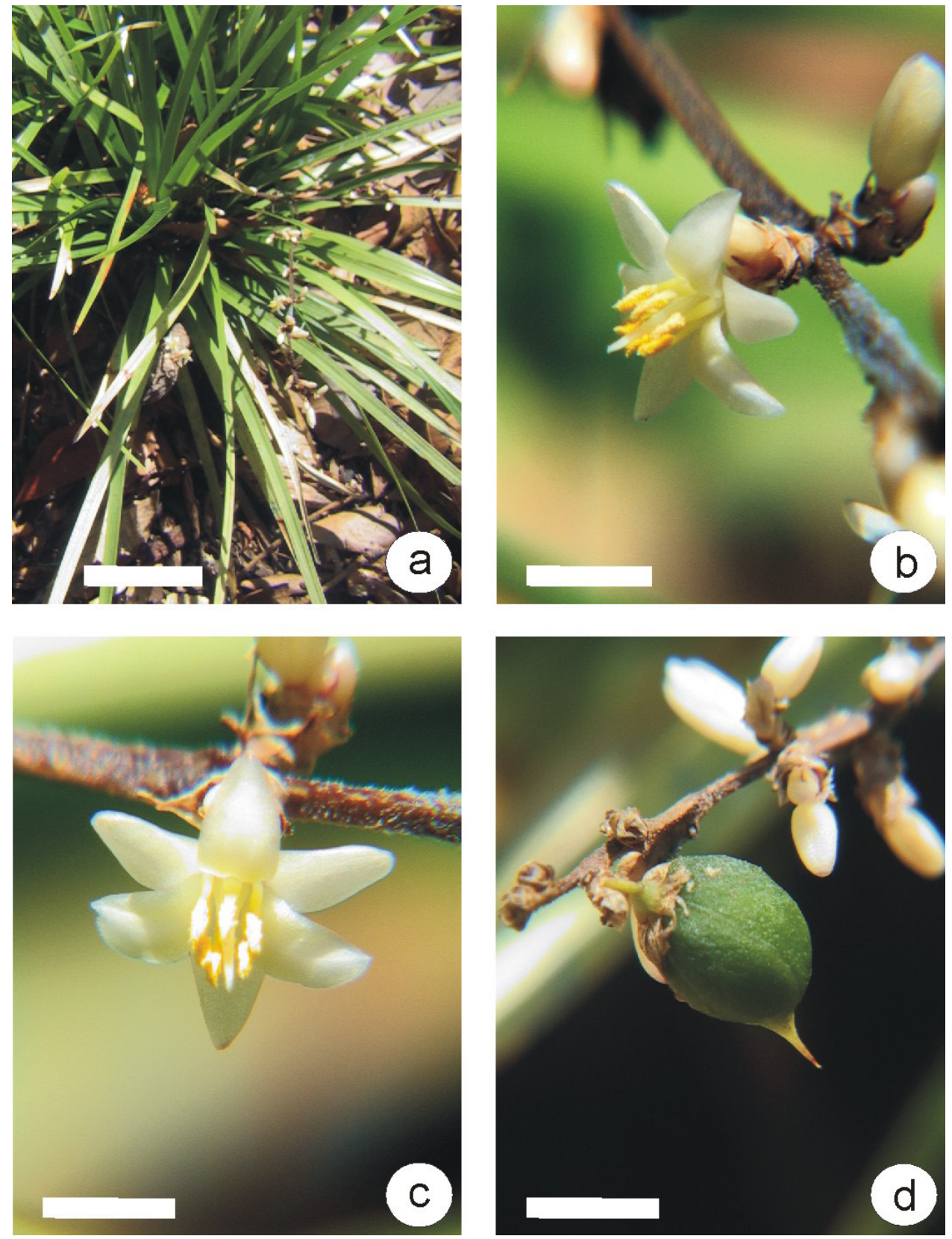

Fig. 4. Romnalda ophiopogonoides Conran, P.I.Forst et Donnon. a, plant; b, flower and buds, lateral view showing persistent bracts c, flower, front view showing straight style and conspicuous scattered wax crystals on the peduncle; d, developing fruit showing asymmetrical development and stylar beak, from Conran 2298 (ADU). Scale bars $\mathbf{a},=20 \mathrm{~mm}, \mathbf{b}-\mathbf{d},=2 \mathrm{~mm}$. 
flowers clustered in branch axils and along branches. Flowers white, each subtended by a small, brownish purple persistent bract. Outer perianth whorl of 3 sepals deltoid, 3.0$3.5 \mathrm{~mm}$ long and 1-1.2 mm wide, abaxial apex purple. Inner perianth whorl of 3 petals ovate-elliptic, 3.5-4 mm long and 1.1-1.4 mm wide. Stamen filaments basally narrowtriangular, pale cream, outer 3 to $2.0 \mathrm{~mm}$ long, fused basally to sepals for $0.25 \mathrm{~mm}$, inner 3 to $2.0 \mathrm{~mm}$ long, fused basally to petals for $0.75 \mathrm{~mm}$; anthers c. $0.6 \mathrm{~mm}$ long. Ovary c. $0.75 \mathrm{~mm}$ long; style $1.75-2.25 \mathrm{~mm}$ long, straight or curved apically, tapering, stigma minute. Capsule hemispherical, 7-9 mm long, 5-6 mm wide, somewhat flattened and tapering into a long, persistent stylar beak abaxially (at least in immature fruit). Seed not seen. Chromosome number $n=8,2 n=16$ (Fig. 3, voucher Sankowsky 2717).

Etymology: the specific epithet is derived from the generic name Ophiopogon (Greek for snake's beard) and the Greek suffix -oides (meaning 'to resemble'); in reference to the resemblance of this species to the widely cultivated Ophiopogon japonicus (Thunb.) Ker Gawl. (Mondo Grass).

Habitat: the new species grows in generally low altitude $(<800 \mathrm{~m})$ rainforests (complex mesophyll to notophyll vineforests; Webb 1959) on substrates derived from granites or metamorphics. It occurs as a forest floor herb in extremely low light, high moisture and high humidity environments. These habitats are characterised by high species endemism and diversity, indicating long term environmental stability, apart from occasional devastation by cyclones (Tracey 1981, Crisp et al. 2001).

Distribution: currently only known at four localities in the Cape Tribulation area (Fig. 5) along the upper Cooper Creek, Roaring Meg Creek, and near Mt Sorrow in Daintree NP.

Conservation status: this species has a limited distribution, small total population size (c. 500 plants) and many of the known plants are exposed, e.g. growing along walking tracks or in unprotected areas subject to human impact and/or development. Moreover, given the mutual potential genetic contamination in areas where the species is sympatric with the equally rare $R$. grallata, conservation of both taxa becomes an issue. There is some overlap in flowering times between them, and both species and their hybrids appear to be self-compatible and capable of introgression (Shapcott 2006). Romnalda ophiopogonoides can be categorised as Endangered on the basis of the criteria A4c,e; B2(i-v),D2 (IUCN 2001).

Specimens examined: Queensland: Cook District: Roaring Meg Creek just below junction with Alexandra Creek, L.J. Webb 11667 \& J.G. Tracey, Jun 1973 (BRI); Roaring Meg Creek near Mt Pieter Botte, Daintree National Park, A. Shapcott RGC7, 5 Nov 2003 (BRI); Track to Mt Sorrow razorback, Daintree National Park, A. Shapcott RGC6, 3 Jun 2003 (BRI); End of Turpentine Road, Little Cooper Creek, A. Shapcott RGC4, 2 Jun 2003 (BRI); Headwaters of Cooper Creek, $3.5 \mathrm{~km}$ W of Thornton Beach, P.I. Forster PIF4402 \& M.C. Tucker, 17 Jun 1988 (BRI, CANB); Turpentine road, Cooper Creek, L.W. Jessup GJD2814 \& al., 26 Nov 1989 (BRI); Near Cooper Creek, G. Sankowsky 655 \& N. Sankowsky, 13 Sep 1987 (BRI); Near Cooper Creek, G. Sankowsky 2717, Dec 2006 (BRI, ADU).

Notes: flowering occurs over an extended period, but mainly from June to November. In cultivation, plants flower more or less continuously across the year, with buds, flowers and fruits all carried at the same time (Conran pers. obs.) but fruit are almost unknown in the field (G. Sankowsky pers. comm.). Flowering in Romnalda ophiopogonoides also follows an altitudinal gradient, with the latest flowering populations occurring at higher, cooler altitudes (Shapcott et al. 2006). 
Romnalda ophiopogonoides is closest to R. grallata and then to R. papuana, although it is distinct genetically (Shapcott et al. 2006), morphologically (Table 1) and anatomically (Table 2). Genetically it differs mainly in allelic frequencies rather than unique alleles, but the degree of difference is comparable with that seen between the other species, supporting recognition at specific rank. Although there is some evidence of hybridisation with $R$. grallata when they are sympatric, they remain distinct at most localities. Flowering time seems to be climate-determined in Romnalda and altitudinal variation in flowering for R. ophiopogonoides seems to maintain genetic isolation of the populations, as well as maintaining reasonable levels of reproductive isolation from R. grallata (Shapcott et al. 2006).

\section{Key to the species of Romnalda}

1 Style shorter than ovary. 2

$1^{*}$ Style at least twice as long as ovary

2 Plants less than $0.5 \mathrm{~m}$ tall; flower clusters along non-elongating branches, in axils and subterminal; leaves with 5-12 apical teeth

R. papuana

$2^{\star}$ Plants over $0.5 \mathrm{~m}$ tall; flower clusters sub-terminal, floral axis elongating; leaves without apical teeth (or rarely $1-3$ )

R. strobilacea

3 Plants less than $15 \mathrm{~cm}$ tall; leaves mostly with 3 (rarely 4 or 5) apical teeth; style straight or apically curved; fruit flattened abaxially

R. ophiopogonoides

$3^{*}$ Plants more than $15 \mathrm{~cm}$ tall; leaves with 4-8 apical teeth; style apically geniculate; fruit globular

$R$. grallata

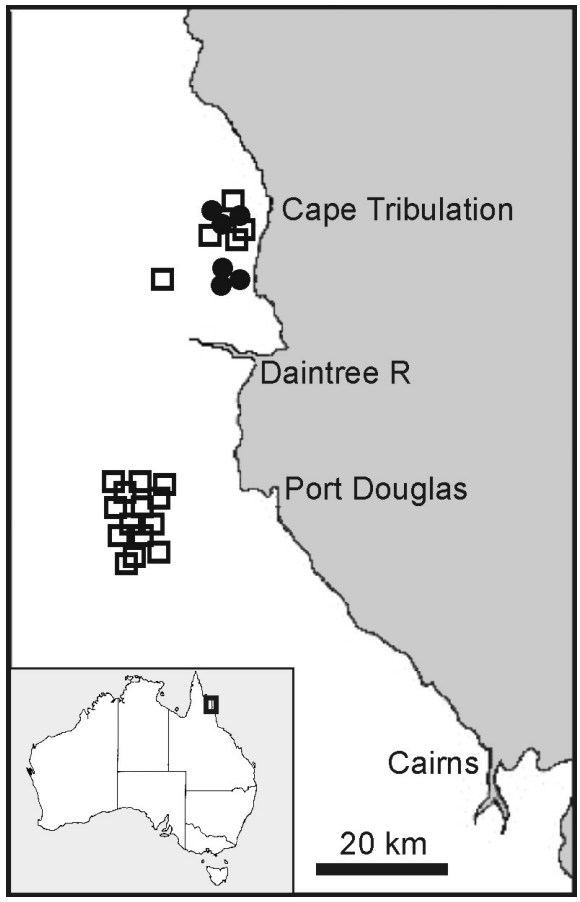

Fig. 5. Distribution of Romnalda ophiopogonoides $(\bullet)$ and R. grallata ( $\square$ ) in the Wet Tropics bioregion of north-east Queensland. 


\section{Acknowledgments}

Live material was supplied by the Flecker Botanic Gardens, Cairns; Bulluock Creek Nursery (Meldale, Qld) and Beantree Nursery (Malanda, Qld. Gary Sankowsky provided collections, photographs and comments on the ecology of the new species. Alison Shapcott (University of the Sunshine Coast) is thanked for information on genetic diversity and conservation status in the genus. The School of Earth and Environmental Sciences at The University of Adelaide provided facilities to undertake this study.

\section{References}

Briggs BG (1986) Chromosome numbers in Lomandra (Dasypogonaceae). Telopea 2: 741-744. Christophel DC \& Lys SD (1986) Mummified leaves of two new species of Myrtaceae from the Eocene of Victoria, Australia. Australian Journal of Botany 34: 649-662.

Conger AD \& Fairchild LM (1953) A quick-freeze method for making smear slides permanent. Stain Technology 28: 281-283.

Conran JG (1997) A preliminary investigation of leaf venation and cuticle features to characterise taxa within Cordyline Comm. ex R.Br. (Agavaceae s.l.). Pp. 71-89 in Dransfield J, Coode MJE \& Simpson DA (eds) Plant Diversity in Malesia III. (Royal Botanic Gardens, Kew: London).

Conran JG (1998) Lomandraceae. Pp. 354-365 in Kubitzki K (ed.) The Families and Genera of Vascular Plants. Vol. 3. Flowering Plants. Monocotyledons: Lilianae (except Orchidaceae). (Springer Verlag: Berlin).

Crisp MD, Laffan S, Linder HP \& Monro A (2001) Endemism in the Australian flora. Journal of Biogeography 28: 183-198.

DEH (2006) EPBC Act List of Threatened Flora (http://www.deh.gov.au/cgi-bin/sprat/public/ publicthreatenedlist.pl?wanted=flora) (Downloaded 15 Dec 2007)

Forster PI (1994) Xanthorrhoeaceae. Pp. 340-341 in Henderson RJF (ed.) Queensland Vascular Plants - Names and Distribution. (Queensland Department of Environment \& Heritage: Indooroopilly).

Forster PI (1997) Xanthorrhoeaceae. Pp. 207-208, in Henderson RJF (ed.) Queensland Vascular Plants - Names and Distribution. (Department of Environment: Brisbane).

Forster PI (2002) Xanthorrhoeaceae. Pp. 198-199 in Henderson RJF (ed.) Names and Distribution of Queensland Plants, Algae and Lichens. (Environmental Protection Agency: Brisbane).

Heads M (2001) Birds of paradise, biogeography and ecology in New Guinea: a review. Journal of Biogeography 28: 893-925.

Henderson RJF (1986) Xanthorrhoeaceae, 2. Romnalda. Pp. 91-92, in George AS (ed.) Flora of Australia, vol 46. (Australian Government Publishing Service: Canberra).

IUCN (2001) IUCN Red List Categories and Criteria: Version 3.1. IUCN Species Survival Commission. (IUCN: Gland and Cambridge).

Logan River Branch SGAP (Queensland Region) Inc. (2005) Mangroves to mountains. Vol. 2. A field guide to the native plants of south-east Queensland. (Logan River Branch SGAP (Qld Region) Inc.: Browns Plains, Qld).

Prakash N (2000) Methods in Plant Microtechnique. 3rd edition. (University of New England: Armidale).

Shapcott A, Bau B, Katik P \& Powell M (2006) Effects of fragmentation, hybridization and climate change on the genetics of the rare rainforest genus of herbs Romnalda from New Guinea and Australia and the implications for species conservation and recovery. Maroochydore, Queensland, Technical Report on the Results of an Internal Research Grant, University of the Sunshine Coast. 1-56.

Stevens PF (1978) Generic limits in the Xeroteae (Liliaceae sensu lato). Journal of the Arnold Arboretum 59: 129-155. 
Tracey JG (1981) Australia's rainforest: where are the rare plants and how do we keep them? Pp. 165-178, in Synge H (ed.) The Biological Aspects of Rare Plant Conservation. (John Wiley and Sons Ltd: New York).

van Steenis, CGGJ (1985) The Australasian element in Malesia. Brunonia 8: 349-372.

Wang J (2007) Laxmanniaceae. Pp. 99, in Bostock PD \& Holland AE (eds) Census of the Queensland Flora 2007. (Environmental Protection Agency: Brisbane).

Webb LJ (1959) A physiognomic classification of Australian rain forests. Journal of Ecology 47: 551-570.

Manuscript received 12 December 2007, accepted 22 April 2008 